\title{
Analisis Faktor yang Berpengaruh terhadap Keberhasilan Penyediaan Rumah Khusus
}

\author{
Maria Handayani Setyaningrum 1), Sriyana ${ }^{2)}$ dan Bambang Purwanggono ${ }^{3}$ \\ 1,2,3) Universitas Diponegoro, Semarang, Indonesia \\ 1) setyaningrum.mh@gmail.com
}

\begin{abstract}
ABSTRAK
Penyediaan perumahan bagi masyarakat berpenghasilan rendah diakomodir oleh Direktorat Jenderal Penyediaan Perumahan salah satunya melalui penyediaan Rumah Khusus yang dilakukan oleh Direktorat Rumah Khusus. Penelitian ini menganalisa secara bersamaan faktor-faktor yang berpengaruh dengan pemodelan SEM untuk melihat secara empiris pengaruh masing-masing faktor terhadap keberhasilan penyediaan rumah khusus. Hasil pengujian dengan menggunakan SEM diperoleh hasil bahwa faktor kerjasama antar stakeholder berpengaruh terhadap jumlah rumah khusus terbangun. Indikator kinerja utama penyediaan rumah khusus adalah jumlah rumah khusus terbangun, artinya kerjasama antar stakeholder berpengaruh terhadap keberhasilan penyediaan rumah khusus. Pemerintah pusat perlu mendorong adanya penguatan kelembagaan di daerah supaya tercipta kerjasama antar stakeholders yang lebih baik, meningkatkan pendidikan dan pelatihan sumber daya aparatur yang berkaitan dengan perencanaan dan pelaksanaan kerjasama sehingga lebih banyak inovasi kerjasama dapat tercipta, mendorong peran Pokja Perumahan dan Kawasan Permukiman di setiap daerah guna mencari solusi permasalahan pembangunan di daerah yang melibatkan dinas terkait, pihak swasta dan masyarakat sehingga tidak terjadi tumpang tindih usulan kepada Pemerintah Pusat.
\end{abstract}

DOI: https://doi.org/10.21107/rekayasa.v12i2.5854

Kata Kunci: Analisis, Faktor Keberhasilan, Penyediaan Perumahan, Rumah Khusus, SEM.

\section{ABSTRACT}

\section{Analysis of Special Housing Provisions' Success Factors}

Provision of housing for low-income people is accommodated by the Directorate General of Housing Provision, one of which is through the provision of special housing by the Directorate of Special Housing. This study analyzes simultaneously the influential factors with SEM modeling. The results shows that the collaboration factor between stakeholders influences the number of special housing built. The main performance indicator for the provision of special housing is the number of special houses built. It means that collaboration between stakeholders influences the success of providing special housing. The special housing provision program really requires the commitment and active role of all stakeholders involved in the provision of special housing for the achievement of effective policy objectives.

Keywords: Analysis, Housing Provision, SEM, Special Housing, Success Factors.

\section{PENDAHULUAN}

Keberhasilan pembangunan yang ingin dicapai oleh Direktorat Jenderal Penyediaan Perumahan Kementerian Pekerjaan Umum dan Perumahan Rakyat dapat terlihat dengan pencapaian penyelesaian fisik bangunan dan penyerapan anggaran sehingga bangunan yang sudah selesai dibangun tersebut dapat segera dihuni ataupun dimanfaatkan oleh masyarakat yang benar-benar membutuhkan hunian yang layak. Meskipun tingkat capaian pemenuhan target rumah khusus terbangun setiap tahun anggaran terbilang tinggi, bukan berarti tidak ada hambatan dalam pelaksanaan konstruksi penyediaan rumah khusus. Menurut Sulaiman et al. (2017), dalam pelaksanaan konstruksi ditemui berbagai macam hambatan, antara lain terlambatnya lelang, kurang-

\section{Article History:}

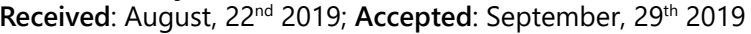
ISSN: 2502-5325 (Online) Terakreditasi Peringkat 3 oleh Kementerian Riset, Teknologi dan Pendidikan Tinggi (ARJUNA), berdasarkan Keputusan Direktur Jenderal Penguatan Riset dan Pengembangan No: 23/E/KPT/2019 tanggal 8 Agustus 2019 nya ketelitian pada saat membuat penjadwalan aktivitas proyek secara rinci dalam pelaksanaan proyek sangat berpengaruh terhadap keterlambatan pelaksanaan di lapangan dan adanya permintaan CCO (Contract Change Order) dimana ada ketidaksesuaian volume pekerjaan dengan kontrak semula. Berangkat dari latar belakang dan pemikiran tersebut di atas, maka fokus masalah penelitian adalah tingkat pengaruh dari faktor-faktor yang berpengaruh terhadap jumlah rumah khusus terbangun dari sudut pandang pemerintah pusat dan keberhasilan dalam penyediaan rumah khusus disini dilihat dari tingkat capaian jumlah unit rumah khusus terbangun Dari berbagai hasil penelitian terdahulu yang digunakan sebagai referensi pada penelitian ini maka didapatkan hal-hal sebagai berikut:

\section{Cite this as:}

Setyaningrum, M.H. Sriyana, S. \& Purwanggono, B. (2019). Analisis Faktor yang Berpengaruh terhadap Keberhasilan Penyediaan Rumah Khusus. Rekayasa, 12(2), 126-134. doi: https://doi. org/10.21107/rekayasa.v12i2.5854

(c) 2019 Maria Handayani Setyaningrum, Sriyana, Bambang Purwanggono 


\section{Ketersediaan Lahan}

Di dalam Peraturan Menteri Pekerjaan Umum dan Perumahan Rakyat No. 20/PRT/M/2017 (Kementerian Pekerjaan Umum dan Perumahan Rakyat, 2017) disebutkan bahwa lahan untuk lokasi penyediaan rumah khusus merupakan milik pengusul bantuan, sementara kebanyakan pengusul tidak mampu menyediakan lahan siap bangun. Menurut Olayiwola et al.(2005), pemerintah perlu alternatif strategi untuk pembangunan rumah. Misalnya, pemerintah dapat menyediakan tanah. Sementara Santosa (2012) berpendapat Guna memfasilitasi penyediaan rumah, aspek lahan menjadi kendala besar bagi pemerintah kota/ daerah. Berdasarkan penelitian Wirabrata \& Surya (2011), masalah pengadaan tanah merupakan masalah utama.

Dalam penyediaan lahan guna penyediaan rumah khusus perlu memperhatikan indikator di bawah ini:

\section{a. Bukti Legalitas Lahan}

Sesuai Peraturan Menteri Pekerjaan Umum dan Perumahan Rakyat No.20/PRT/M/2017 tentang Penyediaan Rumah Khusus (Kementerian Pekerjaan Umum dan Perumahan Rakyat, 2017) di dalam dokumen proposal Penyediaan Rumah Khusus yang disampaikan harus terlampir bukti legalitas kepemilikan hak atas tanah oleh penerima Penyediaan Rumah Khusus dan surat keterangan kesesuaian rencana tata ruang wilayah kabupaten atau kota.

b. Kesiapan Lahan

Sesuai Peraturan Menteri Pekerjaan Umum dan Perumahan Rakyat No. 20/ PRT/ M/ 2017 tentang Penyediaan Rumah Khusus (Kementerian Pekerjaan Umum dan Perumahan Rakyat, 2017), calon penerima Penyediaan Rumah Khusus juga harus menyampaikan surat yang menyatakan bahwa tanah tidak dalam sengketa dan kondisi tanah siap bangun. Akan tetapi menurut Direktorat Jenderal Penyediaan Perumahan dalam LAKIP 2015, LAKIP 2016 dan LAKIP 2017, dalam prosesnya kendala yang dihadapi antara lain ketersedian tanah yang belum clear and clean dan banyak lokasi yang memerlukan pematangan lahan.

\section{Politik (Yang Dimaksud Pada Variabel Ini Ada- lah Terkait Dengan Political Will)}

Penelitian Mailasari (2017) menyebutkan bahwa lingkungan sosial, ekonomi dan politik yang tidak kondusif dapat menjadi sumber masalah dari kegagalan kinerja implementasi kebijakan. Menurut Olayiwola et al. (2005) masalah politik partai di Nigeria memengaruhi keberhasilan Proyek Peru- mahan. Misalnya, sikap tidak kooperatif yang diadopsi oleh beberapa pemerintah negara bagian semata-mata karena pihak yang berbeda selain mereka sendiri yang mengendalikan administrasi di tiap-tiap Negara bagian. Pereira et al. (2015) menyampaikan bahwa campur tangan politik berperan dalam perencanaan pembangunan permukiman. Berdasarkan uraian tersebut maka indikator-indikator dari political will adalah:

a. Dukungan dari Pemimpin Daerah Menurut Staf Ahli Menteri PPN Bidang Pemerataan dan Kewilayahan (2017) adanya perubahan kebijakan pemerintah daerah karena adanya pergantian pimpinan kepala daerah ikut berpengaruh terhadap keberlanjutan program inovasi di daerah. Pada sisi inisiator program (terutama pemerintah daerah), penguatan kelembagaan salah satunya perlu dilakukan melalui penetapan tupoksi yang jelas bagi institusi yang diberi kewenangan untuk pelaksanaan dan pengelolaan program inovasi. Penetapan tupoksi bagi Organisasi Perangkat Daerah (OPD) yang berwenang dapat ditetapkan melalui peraturan Kepala Daerah. Hal ini juga untuk lebih menjamin keberlangsungan program dalam jangka waktu yang lebih panjang. Sesuai Peraturan Menteri Pekerjaan Umum dan Perumahan Rakyat No.20/PRT/M/2017 tentang Penyediaan Rumah Khusus (Kementerian Pekerjaan Umum dan Perumahan Rakyat, 2017), seluruh surat usulan dan pernyataan ditandatangani oleh Pemimpin Penerima Penyediaan Rumah Khusus, dalam hal ini adalah Pemimpin Daerah.

\section{b. Dukungan Wakil Rakyat}

Di dalam masing-masing komisi I sampai dengan XI terdapat komisi di bidang anggaran, dan bersama dengan Badan Anggaran mempunyai tugas dalam hal penetapan alokasi anggaran. Tugas komisi di bidang anggaran salah satunya adalah membahas dan menetapkan alokasi anggaran untuk fungsi, program, dan kegiatan kementerian/lembaga yang menjadi mitra kerja komisi (Direktorat Penyusunan APBN Direktorat Jenderal Anggaran Kementerian Keuangan, 2014).

Sesuai dengan hasil Rapat Dengar Pendapat Komisi V DPR RI (2018), bahwa Komisi V DPR RI bersama dengan Ditjen Cipta Karya, Ditjen Penyediaan Perumahan dan Ditjen Pembiayaan Perumahan Kementerian Pekerjaan Umum dan Perumahan Rakyat akan memperjuangkan anggaran sesuai dengan usulan pagu indikatif TA 2019 yang diusulkan untuk membiayai program-program prioritas sesuai dengan mekanisme pembahasan mengenai RUU tentang APBN di DPR RI. 
128 | Setyaningrum, M.H. dkk., Analisis Faktor yang Berpengaruh terhadap Keberhasilan...

\section{Anggaran}

Keberhasilan implementasi kebijakan sangat tergantung dari kemampuan memanfaatkan sumber daya yang tersedia, karena untuk melakukan sebuah program dana harus mencukupi agar tercapainya program (Mailasari, 2017). Dari penelitian Pereira et al. (2015) diketahui bahwa terdapat ketidakseimbangan antara pertambahan penduduk dengan kemampuan pemerintah untuk menyediakan permukiman. Samosir (2017) berpendapat bahwa minimnya anggaran merupakan faktor penghambat. Hal ini selaras dengan pendapat Santosa (2012) bahwa guna memfasilitasi penyediaan rumah aspek anggaran menjadi kendala besar. Sementara menurut Ritohardoyo (2015) pemerintah pusat sebagai pengambil kebijakan utama memiliki kewajiban terkait dengan alokasi anggaran pembangunan perumahan.

Indikator-indikator anggaran adalah sebagai berikut:

a. Urgensi Kebijakan

Sejalan dengan dinamika perubahan anggaran, terjadi perubahan pagu anggaran sebanyak 6 (enam) kali dengan berbagai prioritas kebijakan (Direktorat Jenderal Penyediaan Perumahan, 2016). Selain itu, akibat adanya beberapa kali kebijakan pemotongan anggaran dan adanya self blocking anggaran mempengaruhi kecepatan penyerapan anggaran (Direktorat Jenderal Penyediaan Perumahan, 2017). Hal ini mengurangi anggaran guna pelaksanaan konstruksi.

b. Regulasi

Adanya Perubahan Struktur Organisasi, sehingga Pelantikan Pejabat Eselon I pada bulan Mei 2015 dan Pejabat Satker dan PPK baru dilantik pada awal April 2015, serta DIPA terbit pada bulan Juni 2015. Selain itu Pejabat Satker dan PPK baru bisa melaksanakan kegiatan setelah dilakukan proses likuidasi terhadap Satker yang lama (Direktorat Jenderal Penyediaan Perumahan, 2015). Pada TA 2016, terjadi Revisi DIPA sebanyak 6 kali terjadi pada periode bulan Februari sampai dengan September 2016 (Direktorat Jenderal Penyediaan Perumahan, 2016). Hal ini menghambat proses kontrak dan pelaksanaan pekerjaan konstruksi.

\section{Kerjasama Antar Stakeholder}

Kebijakan akan efektif jika melibatkan publik dalam seluruh tahap, realistik, transparan, jelas tolok ukur keberhasilan dari program tersebut, jelas target atau sasarannya, jelas dasar hukumnya dan antar kebijakan tidak tumpang tindih dan bertentangan (Arieffiani, 2014). Dari penelitian Rito- hardoyo, (2015) diketahui bahwa kerjasama antar stakeholder merupakan faktor keberhasilan dari program pengembangan perumahan. Santosa (2012) berpendapat bahwa dukungan pemerintah kota/ daerah terhadap program sangat penting. Sementara menurut Wahyudin (2017), faktorfaktor yang mempengaruhi implementasi kebijakan berkaitan dengan program adanya kerjasama kelembagaan baik di dalam struktur birokrasi pemerintah atau di luar pemerintah secara terpadu serta keterlibatan masyarakat. Stakeholders yang dimaksud dalam penelitian ini adalah Pemerintah Pusat, Pemerintah Daerah dan masyarakat.

Dalam penerapan kerjasama antar stakeholder pada penyediaan rumah khusus, indikator-indikatornya adalah sebagai berikut:

a. Komunikasi antar stakeholder

Menurut Pereira et al. (2015), komunikasi antar instansi terkait dengan perencanaan pembangunan permukiman dimana koordinasi komunikasi diantara pihak-pihak yang terlibat sering mendapat masalah selain itu dalam mengidentifikasi kondisi di lapangan dengan penyesuaian data yang ada di Instansi kementerian lain yang terlibat dalam tim koordinasi sering mengalami kontradis dalam dokumen rencana. Wahyudin (2017) berpendapat pelaksana dari kebijakan berkaitan dengan program dan juga para aktor pembuat kebijakan dapat melihat ketidakjelasan informasi atau sosialisasi yang menjadikan program tersebut tidak dapat dimengerti apa sesunguhnya yang akan diarahkan atau dilaksanakan. Mailasari (2017) menyampaikan dengan melakukan verifikasi, ditemukan banyaknya kekurangan administrasi syarat untuk menjadi penerima program sehingga gagal menerima bantuan. Pada Peraturan Menteri Pekerjaan Umum dan Perumahan Rakyat No. 20/ PRT/ M/ 2017 tentang Penyediaan Rumah Khusus (Kementerian Pekerjaan Umum dan Perumahan Rakyat, 2017) telah disampaikan bahwa Penerima Penyediaan Rumah harus menyampaikan proposal Penyediaan Rumah Khusus, Penerima Penyediaan Rumah Khusus bertanggung jawab atas kebenaran dokumen proposal dan ketepatan sasaran penerima manfaat Penyediaan Rumah Khusus dan Penerima Penyediaan Rumah Khusus telah melaksanakan koordinasi terkait Penyediaan Rumah Khusus.

\section{b. Sinergi antar Stakeholder}

Sinergi merupakan operasi gabungan atau perpaduan unsur untuk menghasilkan output yang lebih baik (Pramono \& Kinasih, 2019). Menurut Mailasari (2017), kebijakan publik yang biasanya bersifat top down yang sangat 
mungkin para pengambil keputusan tidak mengetahui bahkan tak mampu menyentuh kebutuhan, keinginan atau permasalahan yang harus diselesaikan. Kemudian Olayiwola et al. (2005) menyampaikan bahwa banyak proyek perumahan pemerintah dijalankan tanpa program aksi yang efektif dan pengaturan kelembagaan yang sesuai untuk pelaksanaannya. Menurut Wahyudin (2017), keterlibatan masyarakat dalam pelaksanaan program dapat memberikan hal positif misal ketepatan sasaran program, kesesuaian pelaksanaan program terhadap kebutuhan. Pemerintah Kota mengharapkan bahwa pemerintah melakukan pembangunan, sementara pemkot memberikan dukungan lahan, dan perizinan (Santosa, 2012). Hal ini juga disampaikan dalam Peraturan Menteri Pekerjaan Umum dan Perumahan Rakyat No.20/PRT/M/2017 tentang Penyediaan Rumah Khusus (Kementerian Pekerjaan Umum dan Perumahan Rakyat, 2017) bahwa Pemerintah Daerah harus memberikan kemudahan proses perizinan dalam penerbitan izin mendirikan bantuan selain menyediakan lahan yang siap bangun guna penyediaan rumah khusus.

c. Penyediaan infrastruktur dasar oleh Pemerintah Daerah

Olayiwola et al. (2005) menyampaikan bahwa Pemerintah perlu alternatif strategi untuk pembangunan rumah. Misalnya, melayani mereka dengan infrastruktur dasar sebelum menyediakan rumah kepada individu yang membutuhkannya. Hal ini juga sesuai dengan Peraturan Menteri Pekerjaan Umum dan Perumahan Rakyat No.20/PRT/M/2017 tentang Penyediaan Rumah Khusus (Kementerian Pekerjaan Umum dan Perumahan Rakyat, 2017) bahwa Pemerintah Daerah Kabupaten atau kota menyatakan bahwa bersedia menyediakan jalan akses, jaringan listrik dan jaringan air minum ke lokasi Rumah Khusus.

\section{Jumlah Rumah Khusus Terbangun}

Indikator kinerja utama Direktorat Rumah Khusus adalah jumlah unit rumah khusus terbangun. Sehingga dapat disimpulkan bahwa jumlah rumah khusus terbangun di daerah pengusul merupakan wujud tercapainya keberhasilan penyediaan rumah khusus. Menurut Abbas (2015), kebijakan dirasakan langsung manfaatnya oleh masyarakat, jika rumah khusus terbangun sesuai rencana maka akan segera dapat dihuni dan dimanfaatkan oleh calon penghuni. Rumah khusus terbangun ini dicapai dengan indikator-indikator sebagai berikut: a. Pengendalian proyek

Menurut Adinyira et al. (2012), kriteria keber- hasilan dari penyediaan perumahan rakyat dilihat dari manajemen waktu, biaya dan mutu. Berdasarkan LAKIP Laporan Kinerja Direktorat Jenderal Penyediaan Perumahan 2016 dan 2017 diketahui bahwa akses menuju lokasi sulit ditempuh sehingga mengakibatkan keterlambatan pengiriman material, kurangnya tenaga kerja dan kecukupan peralatan dan bahan bangunan untuk percepatan penyelesaian pembangunan Rumah Khusus khususnya yang berada di luar pulau Jawa yaitu antara lain Indonesia bagian tengah dan timur serta pelaksanaan terkendala peralatan, bahan, tenaga kerja, SDM pelaksana dan tenaga dari pengawas yang masih kurang dari segi jumlah dan profesional.

Dari Laporan Akuntabilitas Kinerja Instansi Pemerintah LAKIP SNVT Penyediaan Perumahan Provinsi Maluku Utara TA 2016 (SNVT Penyediaan Perumahan Maluku Utara, 2016) Pelaksanaan Wasdal Penyediaan Rumah Khusus dilaksanakan untuk mengawasi dan mengendalikan pelaksanaan pembangunan rumah khusus pada tahun anggaran yang sedang berjalan. Kegiatan Wasdal dilakukan untuk menunjang agar pelaksanaan pembangunan dapat berlangsung secara tepat waktu, mutu dan biaya. Hal ini juga disampaikan dalam Peraturan Menteri Pekerjaan Umum dan Perumahan Rakyat No. 20/ PRT/ M/ 2017 tentang Penyediaan Rumah Khusus bahwa pengawasan dilakukan untuk mengamati, mengidentifikasi serta mengantisipasi permasalahan untuk pencapaian sasaran.

\section{b. Kepuasan Penghunian}

Menurut Adinyira et al. (2012), kriteria keberhasilan dari penyediaan perumahan rakyat dilihat dari kepuasan, kesehatan dan keamanan lingkungan serta keterjangkauan pengguna dan pertimbangan desain. Salleh (2008) menyampaikan kepuasan penghunian mencerminkan sejauh mana kebutuhan perumahan individu terpenuhi. Keberhasilan dari suatu program perumahan tidak hanya bergantung dari penyediaan unit rumah akan tetapi juga faktor lainnya yang mempengaruhi kebutuhan penghuni. Oleh karena itu, perencanaan pengembangan perumahan harus diintegrasikan dengan penggunaan lahan sehingga sistem transportasi umum yang baik dapat diterapkan secara efisien untuk memenuhi kebutuhan masyarakat berpenghasilan rendah.

\section{METODE PENELITIAN}

Obyek penelitian merupakan obyek yang diteliti 
dan dianalisis. Dimana lingkup obyek penelitian yang ditetapkan disesuaikan dengan permasalahan yang akan diteliti. Karena yang diteliti adalah faktor-faktor yang berpengaruh terhadap keberhasilan Penyediaan Rumah Khusus dari sudut pandang pemerintah pusat selaku pelaksana kebijakan, maka obyek penelitian dalam hal ini adalah personil dari Direktorat Rumah Khusus, Direktorat Perencanaan Penyediaan Perumahan, Satuan Kerja Pengembangan Perumahan dan SNVT Penyediaan Perumahan Provinsi.

Berdasarkan pada kerangka konseptual yang telah dijelaskan dapat diajukan hipotesis sebagai berikut :

1. Hipotesis pertama $(\mathrm{H} 1)$

Faktor ketersediaan lahan berpengaruh signifikan terhadap jumlah rumah khusus terbangun. Hal ini dikarenakan tanpa ketersediaan lahan makan kegiatan penyediaan rumah khusus tidak dapat dilaksanakan.

2. Hipotesis kedua $(\mathrm{H} 2)$

Faktor political will berpengaruh signifikan terhadap jumlah rumah khusus terbangun. Hal ini dikarenakan jika tidak ada political will yang kuat maka kegiatan penyediaan rumah khusus tidak dapat diwujudkan di daerah pengusul. Political will diperlukan untuk mendukung upaya mengatasi masalah kebutuhan rumah bagi masyarakat berpenghasilan rendah melalui penyediaan rumah khusus.

3. Hipotesis ketiga $(\mathrm{H} 3)$

Faktor anggaran berpengaruh signifikan terhadap jumlah rumah khusus terbangun karena untuk melakukan sebuah program, dana harus mencukupi agar tercapainya program.

4. Hipotesis keempat $(\mathrm{H} 4)$

Faktor Kerjasama antar stakeholder berpengaruh signifikan terhadap jumlah rumah khusus terbangun. keberhasilan suatu program pemerintah membutuhkan kerjasama, koordinasi dan kelembagaan pelaksanaan kebijakan pembangunan perumahan supaya tidak tumpang tindih dan bertentangan melalui peningkatan peran pemerintah daerah dan pemangku kepentingan lainnya dalam penyediaan rumah khusus.

5. Hipotesis kelima (H5)

Faktor ketersediaan lahan berpengaruh signifikan terhadap kerjasama antar stakeholder. Pada kegiatan penyediaan lahan, diperlukan suatu kerjasama antar stakeholder mulai dari penentuan lokasi, pembelian lahan, proses sertifikasi dan penetapan Rencana Tata Ruang Wilayah dan sebagainya.

6. Hipotesis keenam (H6)

Faktor political will berpengaruh signifikan terhadap anggaran. Dalam hal penetapan anggaran untuk suatu kegiatan diperlukan adanya political will karena adanya keterbatasan sumber daya dan pilihan. Sehingga political will diperlukan untuk menentukan prioritas penggunaan anggaran.

Teknik analisis data yang digunakan adalah teknik analisis Structural Equational Modelling (SEM). Penggunaan teknik SEM bertujuan untuk mencari gabungan dari dua metode statistik yang terpisah yaitu analisis faktor (factor analysis) dan model persamaan simultan (Simultaneous Equation Modeling). Konsep SEM adalah suatu metode yang menunjukkan keterkaitan secara simultan antar variabel-variabel indikator (yang teramati secara langsung) dengan variabel-variabel laten (yang tidak dapat teramati secara langsung). Prinsip SEM adalah pendekatan terintegrasi dari Analisis Faktor Konfirmatori dan Analisis Jalur (Hair et al. (2006). Namun sebelumnya akan disusun terlebih dahulu diagram jalur dan persamaan strukturalnya. Variabel dan indikator penelitian berdasar hasil tinjauan pustaka yang telah dilakukan penulis tertera pada Tabel 1. Sementara model yang diusulkan terlihat pada Gambar 1.

Tabel 1 Variabel dan indikator penelitian

\begin{tabular}{|c|c|c|c|c|}
\hline Variabel & Indikator & $\begin{array}{l}\text { Kode } \\
\text { Indi- } \\
\text { kator }\end{array}$ & $\begin{array}{l}\text { Kate- } \\
\text { gori }\end{array}$ & $\begin{array}{l}\text { Keteran- } \\
\text { gan }\end{array}$ \\
\hline \multirow[t]{2}{*}{ Lahan } & $\begin{array}{l}\text { Legalitas } \\
\text { Lahan }\end{array}$ & $\mathrm{LL}$ & \multirow[t]{2}{*}{$\begin{array}{l}\text { STB- } \\
\text { SB 1-5 }\end{array}$} & \multirow{11}{*}{$\begin{array}{l}\text { Tingkat } \\
\text { penguku- } \\
\text { ran (skala): } \\
\text { Likert, di- } \\
\text { mana nilai } \\
1=\text { sangat } \\
\text { tidak ber- } \\
\text { pengaruh } \\
\text { dan nilai } \\
5=\text { sangat } \\
\text { berpen- } \\
\text { garuh }\end{array}$} \\
\hline & $\begin{array}{l}\text { Kesiapan } \\
\text { lahan }\end{array}$ & $\mathrm{KL}$ & & \\
\hline \multirow[t]{2}{*}{ Political will } & $\begin{array}{l}\text { Dukungan } \\
\text { Pemimpin } \\
\text { Daerah }\end{array}$ & DPD & \multirow[t]{2}{*}{$\begin{array}{l}\text { STB- } \\
\text { SB 1-5 }\end{array}$} & \\
\hline & $\begin{array}{l}\text { Dukungan } \\
\text { Wakil Rakyat }\end{array}$ & DWR & & \\
\hline \multirow[t]{2}{*}{ Anggaran } & $\begin{array}{l}\text { Urgensi Kebi- } \\
\text { jakan }\end{array}$ & UK & \multirow[t]{2}{*}{$\begin{array}{l}\text { STB- } \\
\text { SB 1-5 }\end{array}$} & \\
\hline & Regulasi & $\mathrm{Rg}$ & & \\
\hline \multirow[t]{3}{*}{$\begin{array}{l}\text { Kerjasama } \\
\text { antar Stake- } \\
\text { holder }\end{array}$} & $\begin{array}{l}\text { Komunikasi } \\
\text { antar Stake- } \\
\text { holder }\end{array}$ & KAS & \multirow[t]{3}{*}{$\begin{array}{l}\text { STB- } \\
\text { SB 1-5 }\end{array}$} & \\
\hline & $\begin{array}{l}\text { Sinergi antar } \\
\text { Stakeholder }\end{array}$ & SAS & & \\
\hline & $\begin{array}{l}\text { Infrastruktur } \\
\text { Dasar }\end{array}$ & ID & & \\
\hline \multirow{2}{*}{$\begin{array}{l}\text { Jumlah Ru- } \\
\text { mah Khusus } \\
\text { (Rusus) } \\
\text { Terbangun }\end{array}$} & $\begin{array}{l}\text { Pengendalian } \\
\text { Proyek }\end{array}$ & PP & \multirow[t]{2}{*}{$\begin{array}{l}\text { STB- } \\
\text { SB 1-5 }\end{array}$} & \\
\hline & $\begin{array}{l}\text { Kepuasan } \\
\text { Penghunian }\end{array}$ & $\mathrm{KP}$ & & \\
\hline
\end{tabular}

Sumber : Hasil Analisis, 2018 


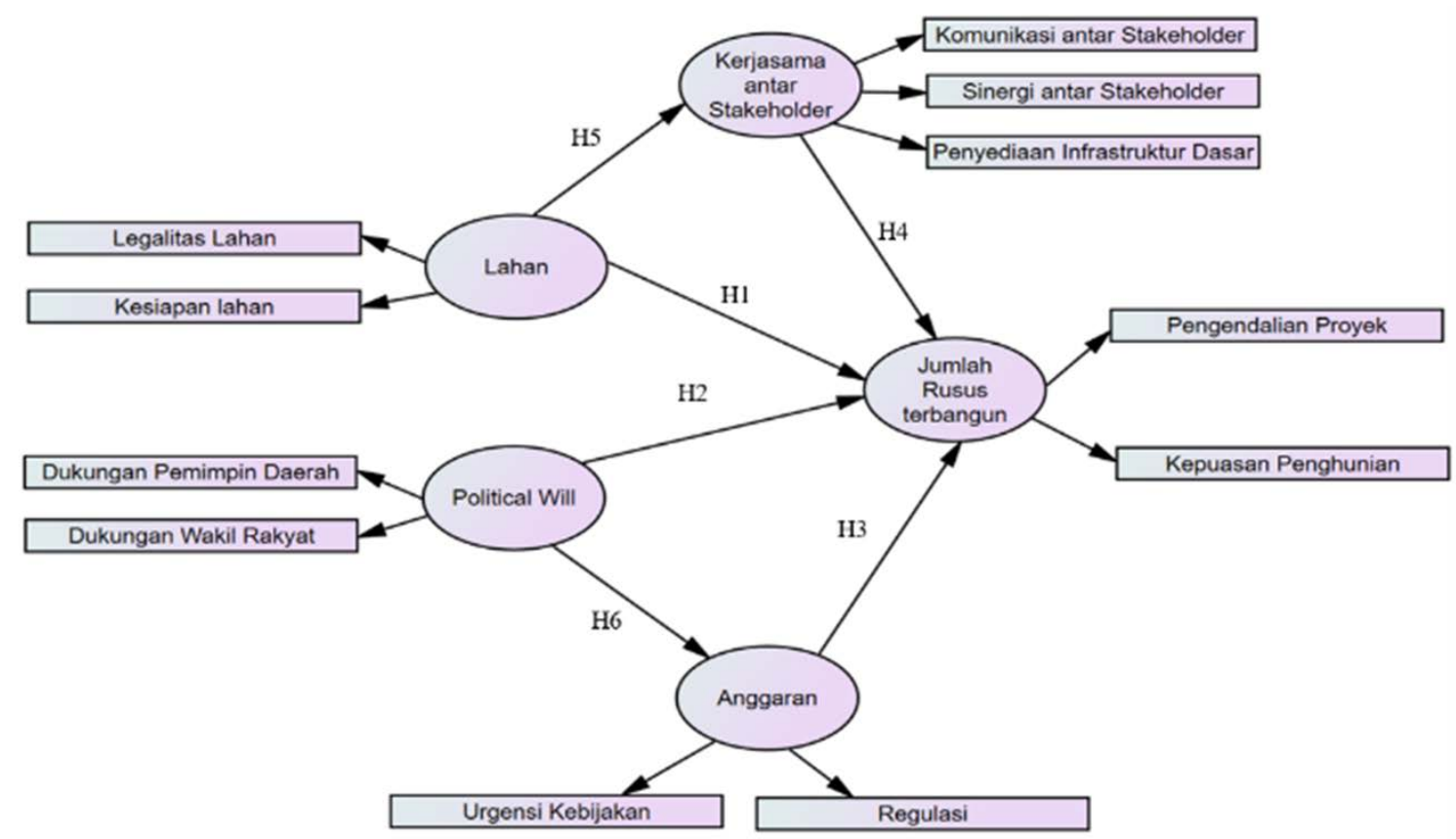

Sumber : Hasil Analisis (2018)

Gambar 1. Model Analisis Penelitian

Tabel 2 Hasil uji inner model

\begin{tabular}{|c|c|c|c|c|c|c|}
\hline & $\begin{array}{l}\text { Original } \\
\text { Sample (O) }\end{array}$ & $\begin{array}{l}\text { Sample } \\
\text { Mean (M) }\end{array}$ & $\begin{array}{l}\text { Standard Devia- } \\
\text { tion (STDEV) }\end{array}$ & $\begin{array}{l}\text { Standard Er- } \\
\text { ror (STERR) }\end{array}$ & $\begin{array}{l}\text { T Statistics } \\
\text { (|O/STERR|) }\end{array}$ & Keterangan \\
\hline $\begin{array}{l}\text { Anggaran -> Jumlah Rusus } \\
\text { Terbangun }\end{array}$ & 0,103 & 0,115 & 0,072 & 0,072 & 1,441 & $\begin{array}{l}\text { H3 ditolak } \\
(<1,96)\end{array}$ \\
\hline $\begin{array}{l}\text { Kerjasama antar stakeholder } \\
\text {-> Jumlah Rusus Terbangun }\end{array}$ & 0,449 & 0,439 & 0,107 & 0,107 & 4,207 & $\begin{array}{l}\text { H4 Diterima } \\
(>1,96)\end{array}$ \\
\hline $\begin{array}{l}\text { Lahan -> Jumlah Rusus } \\
\text { Terbangun }\end{array}$ & 0,155 & 0,153 & 0,105 & 0,105 & 1,471 & $\begin{array}{l}\text { H1 ditolak } \\
(<1,96)\end{array}$ \\
\hline $\begin{array}{l}\text { Lahan -> Kerjasama antar } \\
\text { stakeholder }\end{array}$ & 0,457 & 0,462 & 0,104 & 0,104 & 4,398 & $\begin{array}{l}\text { H5 Diterima } \\
(>1,96)\end{array}$ \\
\hline Political will -> Anggaran & 0,232 & 0,245 & 0,098 & 0,098 & 2,365 & $\begin{array}{l}\text { H6 Diterima } \\
(>1,96)\end{array}$ \\
\hline $\begin{array}{l}\text { Political will -> Jumlah Rusus } \\
\text { Terbangun }\end{array}$ & 0,188 & 0,195 & 0,110 & 0,110 & 1,700 & $\begin{array}{l}\text { H2 ditolak } \\
(<1,96)\end{array}$ \\
\hline
\end{tabular}

\section{Sumber : Data Primer yang diolah, 2019}

\section{HASIL DAN PEMBAHASAN}

Partial Least Square (PLS) meniadakan asumsiasumsi Ordinary Least Squares (OLS) regresi, seperti data harus terdistribusi normal secara multivariate serta tidak adanya masalah variabel eksogen (Ghozali \& Latan, 2012). PLS tidak hanya bisa dipakai guna tujuan eksplorasi, melainkan juga untuk tujuan konfirmasi, seperti pengujian hipotesis (Sanchez, 2009). Meski PLS lebih diutamakan sebagai eksplorasi dibanding konfirmasi, PLS juga dapat digunakan untuk menduga apakah terdapat atau tidak terdapat hubungan dan kemudian proposisi untuk pengujian.

Analisis data dengan menggunakan PLS dilakukan dengan dua tahapan evaluasi, yaitu evaluasi model pengukuran (outer model) dan evaluasi model struktural (inner model). Pengolahan data dilakukan dengan bantuan software SmartPLS 2.0.

Guna menyimpulkan apakah hipotesis diterima atau ditolak, digunakan nilai T-Statistics $>1,96$ yang berarti bahwa nilai original sample estimate adalah positif, yang berarti hipotesa diterima. Hasil pengolahan data bootstrapping dapat dilihat pada Tabel 2.

Untuk menguji pengaruh tidak langsung atau indirect effect dari variabel intervening dapat dilakukan dengan mendapatkan nilai $z$-value menggunakan metode Sobel Test (Baron \& Kenny, 1986) : 
132 | Setyaningrum, M.H. dkk., Analisis Faktor yang Berpengaruh terhadap Keberhasilan...

$$
Z-\text { Value }=\frac{a b}{\sqrt{\left(b^{2} S E_{a}^{2}\right)+\left(a^{2} S E_{b}^{2}\right)}}
$$

Keterangan :

$\mathrm{ab}$ : koefisien indirect effect yang diperoleh dari perkalian antara direct effect $a$ dan $b$.

a : koefisien direct effect independen terhadap intervening.

b : koefisien direct effect intervening terhadap dependen.

SEa: standard error dari koefisien a.

SEb: standard error dari koefisien b.

Untuk mengetahui seberapa besar pengaruh variabel eksogen terhadap variabel endogen, dilakukan evaluasi pada nilai $R$-square. Nilai $R$-square ditampilkan dalam Tabel 3 berikut.

Tabel 3. R-square

\begin{tabular}{ll}
\hline & $R$-Square \\
\hline Anggaran & 0.053751 \\
Jumlah Rusus Terbangun & 0.495515 \\
Kerjasama antar stakeholder & 0.208862 \\
\hline
\end{tabular}

Sumber : Data Primer yang diolah, 2019

Nilai R-square Jumlah Rusus Terbangun sebesar 0,496 yang artinya variabel Anggaran dan Kerjasama Antar Stakeholder secara simultan mampu menjelaskan pengaruhnya terhadap variabel Jumlah Rusus Terbangun sebesar $49,6 \%$ sedangkan $50,4 \%$ dijelaskan oleh variabel lain di luar model yang diteliti.

Hasil pengujian dengan menggunakan SEM diperoleh hasil bahwa hipotesis yang diterima yaitu hipotesa bahwa faktor lahan berpengaruh terhadap faktor kerjasama antar stakeholder $(4,398>1,96)$, faktor kerjasama antar stakeholder berpengaruh terhadap jumlah rumah khusus terbangun $(4,207>1,96)$, dan faktor political will berpengaruh terhadap faktor anggaran $(2,365>1,96)$.

Dari hasil pengujian dapat terlihat bahwa variabel lahan merupakan variabel yang berpengaruh positif terhadap variabel kerjasama antar stakeholder $(4,398>1,96)$. Hal ini berarti semakin tinggi jumlah pengusul yang mampu menyediakan lahan untuk pembangunan rumah khusus akan meningkatkan kerjasama antar stakeholder karena pembangunan rumah khusus membutuhkan komitmen dari berbagai elemen stakeholder.

Faktor kerjasama antar stakeholder berpengaruh signifikan terhadap jumlah rumah khusus terbangun $(4,207>1,96)$, artinya kerjasama antar stakeholder berpengaruh terhadap keberhasilan penye- diaan rumah khusus.

Dari hasil perhitungan Sobel Test, variabel kerjasama antar stakeholder menjembatani variabel lahan dan jumlah rumah khusus terbangun sebagai variabel intervening $(3,305>1,96)$. Variabel lahan tidak berpengaruh secara signifikan jika dihubungkan langsung dengan variabel jumlah rumah khusus terbangun $(1,471<1,96)$, artinya ketersediaan lahan membutuhkan kerjasama antar stakeholder yang tinggi supaya berpengaruh signifikan terhadap jumlah rumah khusus terbangun.

\section{SIMPULAN DAN REKOMENDASI}

Berdasakan hasil penelitian yang telah dilakukan maka kesimpulan yang dapat diambil antara lain bahwa faktor-faktor yang dianalisa adalah faktor ketersediaan lahan, faktor political will, anggaran dan kerjasama antar stakeholder. Indikator Keberhasilan Utama Direktorat Rumah Khusus adalah jumlah rumah khusus terbangun. Sehingga dari hasil permodelan, faktor yang berpengaruh dalam pencapaian keberhasilan Penyediaan Rumah Khusus adalah kerjasama antar stakeholder.

Usulan dari Pemerintah Daerah untuk penyediaan rumah khusus sangat tinggi, akan tetapi anggaran Pemerintah Pusat untuk mengakomodir terbatas. Kerjasama antar stakeholder dalam penyediaan rumah khusus apabila didukung oleh Pemimpin Daerah akan lebih mudah tercapai. Strategi yang dapat diterapkan untuk mengoptimalkan kerjasama antar stakeholders adalah dengan memperkuat komitmen kerjasama antara pemerintah pusat dan pemerintah daerah. Pemerintah pusat perlu mendorong adanya penguatan kelembagaan di daerah supaya tercipta kerjasama antar stakeholders yang lebih baik, meningkatkan pendidikan dan pelatihan sumber daya aparatur yang berkaitan dengan perencanaan dan pelaksanaan kerjasama sehingga lebih banyak inovasi kerjasama dapat tercipta, mendorong peran Pokja Perumahan dan Kawasan Permukiman di setiap daerah guna mencari solusi permasalahan pembangunan di daerah yang melibatkan dinas terkait, pihak swasta dan masyarakat sehingga tidak terjadi tumpang tindih usulan kepada Pemerintah Pusat.

Penelitian ini tentunya tidak terlepas dari beberapa keterbatasan, sehingga penulis menyertakan pula rekomendasi guna penelitian mendatang antara lain pada penelitian selanjutnya sebaiknya memperluas populasi dan responden penelitian di berbagai tingkat penelitian karena tidak semua pihak yang terlibat menjadi subyek dalam penelitian ini. Penelitian selanjutnya mungkin dapat melakukan permodelan dengan variabel-variabel yang 
lebih beragam karena hasil penelitian pengaruh variabel masih menunjukkan adanya pengaruh variabel lain di luar variabel yang diteliti.

\section{DAFTAR PUSTAKA}

Abbas, I. (2015). Evaluasi Kebijakan Pembangunan Rumah Layak Huni Bagi Masyarakat Miskin Di Kota Samarinda Provinsi Kalimantan Timur. Jurnal Paradigma, 4(2), 80-91. Retrieved from http://e-journals.unmul.ac.id/ index.php/JParadigma/article/view/409/369

Adinyira, E., Botchway, E., \& Kwofie, T. E. (2012). Determining Critical Project Success Criteria for Public Housing Building Projects (PHBPS) in Ghana. Engineering Management Research, 1(2), 122-132. https://doi.org/10.5539/emr. v1n2p122

Arieffiani, D. (2014). Kebijakan Pembangunan Perumahan Pemerintah Kota Surabaya Dan Konsistensi Terhadap Pemanfaatan Lahan. Jurnal Sosial Humaniora, 7(1), 45-60.

Baron, R. M., \& Kenny, D. a. (1986). The Moderator-Mediator Variable Distinction in Social The Moderator-Mediator Variable Distinction in Social Psychological Research: Conceptual, Strategic, and Statistical Considerations. Journal of Personality and Social Psychology, 51(6), 1173-1182. https://doi. org/10.1037/0022-3514.51.6.1173

Direktorat Jenderal Penyediaan Perumahan. (2015). Laporan Kinerja Direktorat Jenderal Penyediaan Perumahan 2015. Jakatrta: Kementerian Pekerjaan Umum dan Perumahan Rakyat.

Direktorat Jenderal Penyediaan Perumahan. (2016). LAKIP Laporan Kinerja Direktorat Jenderal Penyediaan Perumahan Tahun 2016. Jakarta: Kementerian Pekerjaan Umum dan Perumahan Rakyat.

Direktorat Jenderal Penyediaan Perumahan. (2017). LAKIP Laporan Kinerja Direktorat Jenderal Penyediaan Perumahan 2017. Jakarta: Kementerian Pekerjaan Umum dan Perumahan Rakyat.

Direktorat Penyusunan APBN Direktorat Jenderal Anggaran Kementerian Keuangan. (2014). DASAR-DASAR PRAKTEK PENYUSUNAN APBN DI INDONESIA Edisi II KEMENTERIAN KEUANGAN REPUBLIK INDONESIA (2nd ed.). Jakarta: Kementerian Keuangan Republik Indonesia.

Ghozali, I., \& Latan, H. (2012). Partial Least Square: Konsep, Teknik dan Aplikasi SmartPLS 2.0 M3. Semarang: Badan Penerbit Universitas
Diponegoro.

Hair, J. F., Black, W. C., Babin, B. J., Rolph, A. E., \& Tatham, R. L. (2006). Multivariete Data Analysis (Sixth). New Jersey: Person Education International.

Kementerian Pekerjaan Umum dan Perumahan Rakyat. (2017). Peraturan Menteri Pekerjaan Umum dan Perumahan Rakyat No. 20/PRT/ M/ 2017 tentang Penyediaan Rumah Khusus. Jakarta: Kementerian Pekerjaan Umum dan Perumahan Rakyat.

KOMISI V DPR RI. (2018). Rapat Dengar Pendapat. Retrieved from http://www.dpr.go.id/dokakd/dokumen/K5-14-ab32ad5b23a021ce1f3f26e3c016f2a3.pdf

Mailasari, N. (2017). Implementasi Program Bantuan Stimulan Perumahan Swadaya Tahun 2016 (Studi Kasus Kota Pekanbaru). Jom FISIP, 4(2), 1-10.

Olayiwola, L. M., Adeleye, O., \& Ogunshakin, L. (2005). Public Housing Delivery In Nigeria: Problems And Challenges. World Congress on Housing: Transforming Housing Environments through the Design, (September), 27-30, 2005.

Pereira, L., Supriyono, B., \& Makmur, M. (2015). Perencanaan Pembangunan Permukiman Sebagai Upaya Peningkatan Kelayakan Hidup Masyarakat. Jurnal Ilmu Sosial Dan Ilmu Politik, 4(2), 221. https://doi.org/2442-6962

Pramono, J., \& Kinasih, W. (2019). Sinergitas Antar Stakeholder Dalam Penyelengaraan Kamtibmas Di Kelurahan Gilingan Kecamatan Banjarsari Kota Surakarta. Research Fair Unisri, 3(1), 298-309. Retrieved from https://ejurnal.unisri.ac.id/index.php/rsfu/article/download/2589/2321

Ritohardoyo, S. (2015). Strategi Pembangunan Rumah Susun Berkelanjutan. Jurnal Patrawidya, 16(3), 391-405. Retrieved from https:// repository.ugm.ac.id/136718/1/2015_2015_ su_ritohardoyo_sb.pdf

Salleh, A. G. (2008). Neighbourhood factors in private low-cost housing in Malaysia. Habitat International, 32(4), 485-493. https://doi. org/10.1016/j.habitatint.2008.01.002

Samosir, S. I. (2017). Implementasi Program Rumah Layak Huni Di Kabupaten Kampar. JOM FISIP, 4(1), 1-15.

Sanchez, G. (2009). Understanding Partial Least Squares Path Modeling (An Introduction with R). Academic Paper, March 2009, Department of Statistics and Operations $R e^{-}$ 
134 | Setyaningrum, M.H. dkk., Analisis Faktor yang Berpengaruh terhadap Keberhasilan...

search, Universitat Politècnica de Catalunya.

Santosa, B. (2012). Kesiapan Dan Kesediaan Pemangku Kepentingan Untuk Peremajaan Kawasan Kumuh Melalui Pembangunan Rumah Susun: Studi Kasus Di Kota Semarang. Jurnal Perkotaan, 4(2).

SNVT Penyediaan Perumahan Maluku Utara. (2016). Laporan Akuntabilitas Kinerja Instansi Pemerintah LAKIP SNVT Penyediaan Perumahan Provinsi Maluku Utara TA 2016. Retrieved from http://weekly.cnbnews.com/ news/article.html?no $=124000$

Staf Ahli Menteri PPN Bidang Pemerataan dan Kewilayahan. (2017). Prakarsa pemerintah daerah dalam upaya pengurangan kesenjangan wilayah dan pembangunan daerah. Jakarta: KEMENTERIAN PERENCANAAN PEMBANGUNAN NASIONAL/ BADAN PERENCANAAN PEMBANGUNAN NASIONAL.
Sulaiman, M., Munirwansyah, \& Azmeri. (2017). Analisis Penyebab Keterlambatan Pelaksanaan Proyek Ditinjau Dari Waktu Pelaksanaan Di Provinsi Aceh. Jurnal Teknik Sipil Universitas Syiah Kuala, 1(2), 405-418.

Wahyudin, D. (2017). Implementasi Kebijakan Dalam Mewujudkan Program Perbaikan Rumah Tidak Layak Huni Di Kecamatan Arcamanik Kota Bandung. Universitas Pasundan Institutional Repositories \& Scientific Journals. Retrieved from http://repository.unpas.ac.id/ id/eprint/27118

Wirabrata, A., \& Surya, T. A. (2011). Masalah Kebijakan Dalam Pengadaan Tanah untuk Pembangunan Infrastruktur. Jurnal Ekonomi Dan Kebijakan Publik, 2(2), 729-752. 